\title{
POLITIKK
}

SKANDINAVISK TIDSSKRIFT

FOR INTERNASIONALE STUDIER

Årgang 78, Nummer 4, side 545-565, 2020, ISSN 1891-1757, www.tidsskriftet-ip.no, Publisert desember 2020

\section{Nobel-initiativet fra 1966 og den lange linjen i norsk freds- og forsoningsdiplomati}

\author{
Martin Eide \\ Gjesteforsker, Fridthjof Nansens Institutt, Norge \\ Iver B. Neumann \\ Fridtjof Nansens Institutt, Norge
}

\begin{abstract}
Sammendrag
Vi har omfattende forskningslitteraturer om hvordan norsk utenrikspolitikk på begynnelsen av 1900-årene kretset om fred, og om fremveksten og institusjonaliseringen av norsk freds- og forsoningsdiplomati fra midten av 1980-årene og til i dag. Vår kunnskap om den mellomliggende perioden og røttene til fredsdiplomatiet er mer mangelfull. Artikkelen sammenfatter det vi vet, og den presenterer en tidligere ukjent case fra 1966-1968, det såkalte Nobel-initiativet, der en gruppe norske borgere gikk sammen om å mobilisere nobelprisvinnere med sikte på å etablere en bakkanal for fredssamtaler mellom USA og Nord-Vietnam. Samfunnsinitiativet fikk helhjertet oppslutning fra den norske stat. Nobel-initiativet er dermed en forløper for det samarbeidet mellom stat og samfunn som skulle prege norsk freds- og forsoningsdiplomati. Gitt at vi også finner løse forelegg for freds- og forsoningsdiplomati i 1920årene, gjør kunnskapen om Nobel-initiativet det mulig å påstå at vi gjennom det siste hundreåret konsistent finner norsk freds- og foroningsdiplomati i den utstrekning og den form som de internasjonale forholdene tillater.
\end{abstract}

Nøkkelord: fredsdiplomati · fred og forsoning • utenrikspolitikk

\footnotetext{
^Kontaktinformasjon: Martin Eide, e-post: m.de@tuta.io

(C)2020 Martin Eide \& Iver B. Neumann. This is an Open Access article distributed under the terms of the Creative Commons Attribution 4.0 International License (http://creativecommons.org/licenses/by/4.0/), allowing third parties to copy and redistribute the material in any medium or format and to remix, transform, and build upon the material for any purpose, even commercially, provided the original work is properly cited and states its license.

Citation: Eide, M. E Neumann, I. B. (2020). Nobel-initiativet fra 1966 og den lange linjen i norsk freds- og forsoningsdiplomati. Internasjonal Politikk, 78(4), 545-565. http://dx.doi.org/10.23865/intpol.v78.2282
} 


\section{Innledning}

Fra 1990-årene av er såkalt freds- og forsoningsdiplomati, altså forløp der Utenriksdepartementet (UD) tilrettelegger for samtaler mellom en stats regime og en organisert intern opposisjon, blitt stadig mer integrert og institusjonalisert i norsk utenrikspolitikk generelt. UD har deltatt i 16 kjente slike prosesser, etter all sannsynlighet i flere. Artikkelen innledes med en oversikt over hva vi vet om dette diplomatiet. Del to av artikkelen drøfter dets historiske forutsetninger. Vi diskuterer tre hypoteser om hvor det kommer fra, under navnene fredstanken, fravær av politisk realismetradisjon og raison de système. De to første hypotesene dreier seg om dyptfestede sosiale forhold på 1800-tallet og begynnelsen av 1900-tallet, mens den tredje først og fremst retter seg mot å forklare hvorfor staten fra 1990-tallet satset så tungt på å tappe dette potensialet i utenrikspolitisk og identitetsmessig henseende. Dette betyr at vi vet forholdsvis lite om betydningen av ting som skjedde i perioden 1905-1990. Del tre, som er hoveddelen av artikkelen, innledes derfor med en kort oversikt over de tilfellene av norsk fredsdiplomati vi kjenner til for denne perioden, før vi presenterer en ikke tidligere studert case, nemlig det såkalte Nobel-initiativet fra 1966. Nobel-initiativet var et idealistisk samarbeid som sprang ut av miljøene rundt Arbeiderbladet og Nobelkomiteen. Målet var å få USA og Nord-Vietnam til å snakke sammen med sikte på fred i Vietnam, virkemidlet var å mobilisere fredsprisvinnere for å skape en såkalt bakkanal som USA og Nord-Vietnam kunne bruke til å etablere en dialog, uformelt og i hemmelighet. Vi anvender de tre hypotesene på materialet for å se om vi kan begynne å utvide deres gyldighetsområde til perioden 1905-1990, og vi konkluderer med at Nobel-initiativet, som det første historiske eksemplet på at staten støtter opp om et samfunnsinitiativ for fredsdiplomati, er et vendepunkt. Det er imidlertid ikke et direkte forelegg for 1990-tallets freds- og forsoningsdiplomati, for dette diplomatiet retter seg mot å tilrettelegge for dialog og forhandlinger mellom et regime og en intern opposisjon i staten der dette regimet hersker. Kirkens Nødhjelps og UDs samarbeid i Etiopia og Eritrea fra midten av 1980-årene er et slikt direkte forelegg. Nobel-initiativet, som ikke siktet seg inn mot å tilrettelegge for fred og forsoning internt i en stat, men mot at Norge skulle spille en tradisjonell tilretteleggende rolle mellom to stater, er, i kraft av samarbeidet mellom samfunn og stat, derimot et indirekte forelegg. Det er også et sammenbindende ledd for norsk fredsdiplomati, for vår viten om Nobel-initiativet reduserer det vi trodde var et hull i norsk fredsdiplomati, fra å være seks tiår langt (fra midten av 1920-årene til midten av 1980-årene) til å være fire tiår langt (fra midten av 1920årene til midten av 1960-årene). Gitt at det også var spredt tilretteleggingsvirksomhet mellom tredjeland i norsk UD i 1950-årene og tidlig i 1960-årene, konkluderer

\footnotetext{
${ }^{1}$ Takk til Bernt Bull, Kim Helsvig, Håkon Ikonomou, Halvard Leira, Dag Thorkildsen, Fredrik Thue, Jakob Skram, Andreas Østhagen og to anonyme fagfeller for kommentarer.
} 
vi med at norsk UD generelt har drevet fredsdiplomati i den form og i den utstrekning den internasjonale situasjonen har tillatt.

\section{Hva vi vet om norsk fredsdiplomati}

Siden begynnelsen av 1990-årene har norsk freds- og forsoningsdiplomati gradvis blitt en integrert og institusjonalisert del av norsk utenrikspolitikk. Diplomatihistorisk er det ikke noe nytt i at en stat spiller en såkalt tredjepartsrolle som tilrettelegger i en konflikt mellom to andre stater. Det det imidlertid er snakk om her, er forsoningsarbeid mellom to parter, hvorav den ene er et regime som behersker en stat, og den andre er en gruppe mennesker som er tilhørende i samme stat, men i opposisjon til regimet som behersker staten. Det nye ligger altså $i$ at Norge bruker ressurser på å tilrettelegge for fred innen en gitt stat. Dette er en diplomatihistorisk innovasjon, for andre staters/imperiers tidligere virksomhet av denne typen foregikk innen en tidligere imperiestat overfor en tidligere koloni, og ikke som en integrert del av diplomatisk virksomhet, men annetsteds i statsapparatet. Offisielt har Norge siden slutten av den kalde krigen vært involvert i slike prosesser i Israel/Palestina, Guatemala, Sri Lanka, Sudan, Colombia, Filippinene, Timor-Leste, Haiti, Burundi, Eritrea, Mali, Nepal, Kypros, Vest-Balkan og Venezuela. I tillegg er det kjent at Norge har lagt til rette for kontakt mellom Herri Batusuna i spansk Baskerland og den spanske stat. Vi må gå ut fra at det også finnes ikke-rapporterte tilfeller.

Opptil flere av disse prosessene er dekket i foreliggende litteratur (se spesielt Nissen \& Waage, 2015; Fixdal, 2016). Det er videre skrevet en god del om hvordan UD organiserer og tenker om dette arbeidet (Neumann, 2015). Spørsmålene om Norges intensjoner og om dette er kostnadseffektiv utenrikspolitikk, har vært gjenstand for en rekke artikler, både politiske og vitenskapelige (for en oversikt, se Harpviken \& Skjelsbæk, 2010).

Norsk freds- og forsoningsdiplomati er imidlertid av interesse, ikke bare fra et rent utenrikspolitisk synspunkt, men også i identitetssammenheng. Identitet, hvem «vi» er, har to komponenter: Hvordan et «vi» presenterer seg for omverdenen, og hvordan omverdenen forstår dette vi-et. Identitet kan altså forstås narrativt. Et «vi» forteller historier om hvem vi-et er, som andre kan godta, forkaste eller omkalfatre. Enhver stat har behov for å fortelle og få aksept for historier, ikke bare om at staten eksisterer, men at de eksisterer som noe spesielt. Dette kalles ofte merkevarebygging, men i og med at det ikke dreier seg om å selge noe, men om å bli akseptert som den og det man vil være, står det mer på spill enn bare inntjening. En stat har behov for å bli sett og lyttet til. For å oppnå dette må det bygges status. Én av måtene å bygge status på er å være tilgjengelig som tredjepart i freds- og forsoningsarbeid. Dermed har staten et incentiv til å trekke på allerede eksisterende samfunnsressurser og nasjonale og internasjonale nettverk for å oppnå øket status (de Carvalho \& Neumann, 2015). Én slik ressurs vil være fredsengasjement. Øyvind Skånland (2010) har studert norske historier om Norge som en "fredsnasjon", og han konkluderer 
med at denne selvoppfatningen står sterkt og har fått økt betydning for norsk identitet generelt siden UD institusjonaliserte sitt freds- og forsoningsarbeid. Vi mangler systematiske studier av i hvilken grad denne historien aksepteres av andre stater. Vi kan imidlertid fastslå at andre stater stadig henvender seg til Norge om å bidra til fredsprosesser, så historien godtas i alle fall i noen grad.

\section{Forutsetninger og forelegg for norsk fredsdiplomati I890-I966}

Freds- og forsoningsarbeid er en økonomisk og potensielt politisk kostbar virksomhet. For 2020 er det budsjettert i overkant av 2 milliarder norske kroner til «fred, sikkerhet og globalt samarbeid» (Finansdepartementet, 2019). Ikke minst gitt at Norges identitet også er involvert, står mye på spill. Omfanget av virksomheten er nok blitt muliggjort av statens oljeinntekter over de siste tre tiårene, men man må gå ut fra at et fenomen som dette, som ikke uten videre kan føres tilbake til politisk nødvendighet på et spesielt historisk tidspunkt, har dype sosiale og idémessige røtter. Også om dette foreligger det anselig litteratur, som fremsetter tre hypoteser, to av dem med henvisning til sosial utvikling på 1800-tallet og tidligere, den tredje med henvisning til hvorfor den norske stat i økende grad har hengt seg på sosiale fredsinitiativer, for så selv å bygge opp kapasitet og ta over initiativet. La oss kalle hypotesene fredstanken, fravær av politisk realismetradisjon og raison de système.

Hypotese nummer én, om hvorfor Norge er engasjert i freds- og forsoningsdiplomati i adskillig høyere grad enn andre stater, peker på en kristen, protestantisk arv der interesse for og engasjement i fred er et gode, fordi det er Guds vilje at mennesker skal leve i fred med hverandre (Der Derian, 1987; Kustermans, 2020). Denne fredstanken ble videreført av norsk og skandinavisk arbeiderbevegelse som, enten i stedet for eller i tillegg til den kristne begrunnelsen, anførte en begrunnelse om solidaritet; en internasjonal arbeiderklasse måtte i solidaritetens navn praktisere fred over landegrensene. Videreføringen var ikke uproblematisk, for innen arbeiderbevegelsen fantes det ikke bare et universalistisk fredsbegrep, men også et klassebestemt sådan, der man så bedring av arbeiderbevegelsens kår som en forutsetning for sosial og internasjonal fred. Organisatorisk ga dette seg på begynnelsen av 1900-tallet utslag i blant annet at Norges fredsforening var for bruk av tredjemannsrollen voldgift som konfliktløsningsmekanisme både nasjonalt og internasjonalt, mens Landsorganisasjonen (LO) og Arbeiderpartiet ikke var det (Agøy, 2000, s. 90). Hovedpoenget er imidlertid at disse to opphavene til fredstanken i norsk tradisjon sto i bestandig kontakt og i en produktiv spenning. Faktisk var det Kristiania Arbeidersamfund som i 1890 ba Bjørnstjerne Bjørnson og Venstre-lederen Wollert Konow (SB) om å gjenopprette Den norske Fredsforening (Agøy, 2000, s. 85; se også Haug, 2012, s. 56). Til denne dag er to av de fem store norske organisasjonene som arbeider med fredsog bistandsspørsmål, kristne (Kirkens Nødhjelp) eller en del av arbeiderbevegelsen (Norsk Folkehjelp). Denne hypotesen gjennomsyrer den historiske og samfunnsvitenskapelige litteraturen (Liland \& Kjerland, 2003; Tvedt, 2003; Leira, 2004, 2005). 
Merk at vår hypotese nummer én er en generell hypotese, som har vært anvendt til å forklare en rekke forskjellige fenomener som til sammen danner en postulert norsk fredstradisjon (Pharo, 2005). Her fokuserer vi imidlertid utelukkende på ett av denne postulerte fredstradisjonens elementer, nemlig freds- og forsoningsdiplomati.

En hypotese nummer to kompletterer den første. Den tar utgangspunkt $i$ at det finnes opptil flere andre stater som har hatt en protestantisk statsreligion der fredstanken har stått sterkt, kanskje først og fremst Sverige og Danmark. Disse statene har ganske riktig også utviklet et anselig fredsdiplomati, men ikke av samme omfang som Norges. Fredsdiplomatiet er heller ikke blitt like integrert og institusjonalisert i statenes generelle utenrikspolitikk som tilfellet er i Norge. Hypotesen er følgelig at den suverene norske staten som kom til i 1905, steg frem i et diskursivt miljø der politisk realistisk tenkning om utenrikspolitikk sto svært mye svakere enn $\mathrm{i}$ noen annen suveren, europeisk samtidig stat, inkludert Sverige og Danmark. Dette hang igjen sammen med den svake norske aristokratiske tradisjonen, for det var i aristokratiske kretser politiske realistiske praksiser var blitt formet, og det var aristokratiet som historisk dominerte militærvesen og diplomati. I Norge dominerte på denne tiden derimot borgerskapet, som var mer opptatt av handel og fred enn av krig (Haug, 2012, s. 52-68). Den nye, svake norske staten oppfattet en stormaktskrig, snarere enn forholdet til en spesifikk annen stat eller situasjonen på et spesifikt saksområde, som trussel nummer én. Dermed ble tenkningen om og innretningen av utenrikspolitikken fra første stund i større grad preget av fredstenkning i Norge enn i andre europeiske stater. Her ligger det også en faktor som kan forklare hvorfor Norge har et mer integrert og institusjonalisert fredsdiplomati enn Finland, for selv om også Finland har et svakt aristokratisk islett, har staten som et resultat av sine bånd til Russland historisk sett en langt sterkere politisk realistisk orientering enn Norge. Hypotese nummer to, om at fravær av politisk realismetradisjon i Norge forklarer variasjon som kommer i tillegg til hypotese nummer én om fredstanken, er blitt fremført av norske forskere på internasjonal politikk (se spesielt Knutsen, Leira \& Neumann, 2016). Merk at hypotesen ikke er at det nøytrale Norge fra 1905 til 1940 førte en idealistisk utenrikspolitikk, for det er rett og slett ikke tilfellet. Norge bidro for eksempel ikke til å styrke Folkeforbundets arbeid for å bygge opp en verdensorden tuftet på kollektiv sikkerhet (Haug, 2012, s. 414, 435). Hypotesen er smalere og postulerer simpelthen at det i Norge ikke fantes noe særlig systematisk tenkning som kunne avvise fredsarbeid på generelt grunnlag, slik det gjorde blant stormaktene og også i Sverige og Danmark. Hypotesen svekkes etter som Norge får et operativt UD, der realistisk tenkning vokser frem, spesielt i kjølvannet av andre verdenskrig. ${ }^{2}$

En tredje hypotese om hvordan fred og forsoning kom til å stå så sentralt i norsk utenrikspolitikk, dreier seg om såkalt raison de système, altså mekanismen hvor en

${ }^{2}$ I mellomkrigstiden er realistisk tenkning først og fremst å finne i enkelte militære kretser (Knutsen, Leira \& Neumann, 2016). 
gitt stat vil ha interesse av å opprettholde og styrke det statssystemet den er en del av, i den formen det eksisterer. Denne hypotesen er kompletterende til hypotese én og to, for den er ment å skulle forklare ikke bare at staten kommer engasjement om fredstanken i møte, men at staten faktisk aktivt omfavner en slik tanke. Det er en generell sosial innsikt at stater historisk har utviklet sitt virkeområde ved å ta over og bygge ut allerede eksisterende sosiale institusjoner. Merk at det vi vet om overtagelse av fredsdiplomati så langt, indikerer at dette ikke skjer historisk før mot slutten av den kalde krigen, altså når omkostningene ved å bygge ut diplomatisk aktivitet som ikke er direkte nødvendig i et politisk realistisk perspektiv, blir mindre. Spillerommet for en mellomstor stat som Norge ble større da stormaktkonflikten ikke i samme grad innskrenket spillerommet (såkalt overlay) (Buzan \& Wæver, 2003). Dermed kunne Norge ta seg råd til å bruke noe mindre ressurser på forholdet til stormakter, hvilket betød at det åpnet seg rom for å gjøre mer av andre ting, for eksempel fredsog forsoningsdiplomati. Også denne hypotesen er blitt fremført av norske forskere på internasjonal politikk (Neumann, 2015).

For å komme videre $\mathrm{i}$ vår forståelse av hvordan fred og forsoning ble sentralt for norsk utenrikspolitikk spesielt og norsk identitet generelt, trenger vi for det første mer teoriutvikling, og for det andre trenger vi bedre empirisk forståelse av hvor relevante disse tre hypotesene var, ikke bare for 1800-tallet og tidlig 1900-tallet, men for perioden mellom første verdenskrig og 1990. Merk at det her oftest er snakk om fredsdiplomati i mer tradisjonell betydning enn den som har rådet grunnen siden 1990, nemlig tradisjonell tredjepartvirksomhet der Norge er tilrettelegger mellom to stater (til forskjell fra mellom et regime og en intern opposisjon). Det er den sistnevnte utfordringen vi vil forsøke å imøtegå i resten av denne artikkelen. I tråd med hypotese nummer én må vi få bedre oversikt over omfanget av konkrete fredsutspill fra sosiale miljøer, også som svar på henvendelser fra nettverk utenfor Norge, for eksistensen av slike utspill er direkte bekreftende for hypotesen, og direkte foregripende for institusjonaliseringen som fant sted fra 1990 av. I tråd med hypotese nummer to må vi få bedre oversikt over i hvilken grad realpolitiske hensyn bremset realiseringen av slike utspill. Spesielt interessant her er i hvilken grad UD sto for bremsingen, for dersom politisk realistisk tenkning var det som sto i veien for at utspillene skulle realiseres, støtter det hypotese nummer to direkte. Hypotese nummer tre er først og fremst ment å forklare integreringen og institusjonaliseringen av norsk freds- og forsoningspolitikk og er derfor først og fremst relevant for perioden etter 1990, men om vi finner eksempler fra tidligere perioder der politiske aktører fremfører raison de système-resonnementer for å støtte fredsdiplomati, støtter det hypotesen.

Vi har ikke noen spesifikke studier av eventuelt norsk fredsdiplomati i perioden frem mot og fra 1905 til slutten av 1940-årene. Norges fredsarbeid i forbindelse med de to Haag-konferansene $(1899,1907)$ og i Den interparlamentariske union var definitivt rettet mot å forebygge og dempe konflikter, men inkluderte ikke konkrete fremstøt for å tilrettelegge for forhandlinger mellom stater (Riste, 2003). At Norge 
fra 1901 av delte ut Nobels fredspris, betød at de involverte i dette arbeidet, som langt på vei var identiske med Norges generelle utenrikspolitiske elite (Haug, 2012; Johnsen 2015; Knutsen, Leira \& Neumann, 2016), fikk mer kunnskap om konkret fredsarbeid, men med enkelte unntak - som prisen til den opposisjonelle tyskeren Carl von Ossietzky i 1935 - gikk prisene til mennesker som var involvert i generelt fredsarbeid, snarere enn til dem som arbeidet med tilretteleggende diplomati stater imellom. En håndfull nordmenn utførte ymse oppgaver for Folkeforbundet - Jonas Lies deltagelse i den internasjonale politistyrken som overvåket folkeavstemningen i Saargebiet i 1935 er ett eksempel - men denne typen arbeid dreiet seg heller ikke om konkret tilrettelegging av diplomatiske samtaler mellom stater eller mellom regimer og deres interne opposisjon. Blant de fire norske diplomatene som arbeidet for Folkeforbundet - Peter Anker, Hans Christian Berg, Erik Colban, Rasmus Skylstad - har imidlertid Haakon Ikonomou trukket frem Erik Colban som en interessant kandidat til rollen som Norges første diplomatiske tilrettelegger. Colban (1876-1956) var utdannet jurist og var allerede en ledende norsk diplomat da han i 1919 ble utpekt som første leder av Folkeforbundets minoritetsavdeling. Dette arbeidet innebar at han i åtte år reiste omkring for å tilrettelegge mellom statlige regimer og en spesifikk type interne grupper som var i opposisjon til disse regimene, nemlig etniske minoriteter. Gram-Skjoldager og Ikonomou (2019, s. 435) oppsummerer som følger:

The first, long-standing, Director of the Section, Norwegian diplomat and trained lawyer Erik Colban, combined 'bureaucratic procedure and active diplomatic relations' to set up 'an international agency in protecting rights'. At the heart of this arrangement lay a petition system, whereby minorities - as individuals or organizations - could send complaints or grievances to the League, which set up a committee system to govern how the Council would investigate petitions. The Minorities Section was entrusted with weeding out petitions by deciding in a preliminary manner on their 'receivability'. Colban travelled extensively on diplomatic missions to the various countries concerned, meeting with representatives of governments, petitioners and other persons interested in the minorities question. By the end of 1924, for instance, Colban and members of the section 'had travelled to Belgrade, Sofia, Bucharest, Transylvania, Athens, Bulgaria, Budapest, Vienna, and Prague multiple times, and Colban was spending around six months each year abroad'. Thus, the work was neither purely legal, nor purely political, and it entailed, particularly on the Director's part, a strong degree of diplomatic finesse.

Ser man på Colbans egen fremstilling av arbeidet for Folkeforbundets avdeling for administrative kommisjoner og minoritetsspørsmål, er det klar overlapp mellom hans beskrivelse av eget praktiske arbeid i 1920-1927 og de fremstillinger norske utøvere av freds- og forsoningsdiplomati fra 1990-årene gir av eget virke (Neumann, 2015). For eksempel skriver han generelt at "[V]årt arbeide skulle vesentlig rettes mot å få i stand direkte kontakt og forhandlingsvilje mellom regjering og minoritet. Folkeforbundet skulle ikke opptre som politimester eller statsadvokat. ... [Jeg] skulle 
normalt ikke ventes å gjøre mer enn å gi råd og veiledning og etter omstendighetene formidle den direkte kontakt mellom regjeringen og minoritetenes talsmenn i landet» (Colban, 1952, s. 84). Hva det spesifikke angår, skriver han om arbeidet i Saar at «[u]nder rådsmøtene i Gèneve kom vanligvis en representant for [den franskledede] regjeringskommisjonen ned for å være til stede. Og det ble skikk og bruk, at en uoffisiell delegasion for Saar-befolkningen også kom. Med medlemmene av denne kommisjonen hadde jeg personlig god forbindelse» (Colban, 1952, s. 74). Alt dette er typisk tilretteleggingsvirksomhet.

Colbans virke er imidlertid ikke noe direkte forelegg for norsk freds- og forsoningsdiplomati, av to prinsipielle grunner, for det første representasjon: Colban opptrådte på vegne av Folkeforbundet, ikke Norge. For det andre, temporalitet: Colbans arbeid dreiet seg ikke om å fremforhandle fred, slik norsk freds-. og forsoningsdiplomati fra 1990-årene av har gjort, men om å implementere allerede inngåtte avtaler, nemlig de minoritetstraktatene de seirende stormaktene hadde pålagt de statene som ble opprettet i Paris 1919 og deretter overlatt til Folkeforbundets avdeling for administrative kommisjoner og minoritetsspørsmål å overvåke implementeringen av. Derimot er Colbans virke et indirekte forelegg. Colban kommuniserte, som alle norske ansatte i Folkeforbundet, hyppig med norsk UD. Det var UD som hadde redet grunnen for deres ansettelse i forbundet, og det var UD de alle sammen siktet mot å komme tilbake til når oppholdet i Genève ville ta slutt (Gram-Skjoldager, Ikonomou \& Kahlert, 2019; se også Stachurska-Kounta, 2017). Vi finner da også utstrakt korrespondanse mellom Colban og utenriksråd Esmarch om nettopp minoritetsspørsmål. ${ }^{3}$ Her fant det altså sted en betydelig kunnskapsoverføring.

I tillegg til Colban kommer et annet forelegg for norsk fred- og forsoningsdiplomati fra 1920-årene, nemlig Fridtjof Nansens godt kjente arbeid i Russland og Kaukasus. Nansen hadde fartstid fra UD som Norges første minister til London, var norsk delegat til Folkeforbundet gjennom hele perioden og var organisasjonens høykommisjonær for flyktninger fra 1921. Hovedproblemet med å tenke en linje fra Nansens arbeid til freds- og forsoningsarbeidet som vokste frem 60 år senere, er imidlertid at Nansen i svært høy grad opererte på egen hånd. Hans arbeid kan verken forstås som fredsarbeid i UDs regi eller som borgeraktivisme rettet mot UD, til det var hans nettverk for internasjonalt, hans syn på norsk UDs betydning for verdensfreden for nedlatende og hans fremgangsmåte for individualistisk (Haug, 2012, 68n.70, s. 397). Ikke desto mindre har vi i Colbans og Nansens folkeforbundrelaterte aktiviteter, som altså også fant sted i margen av norsk UD, løse forelegg for norsk freds- og forsoningsdiplomati. Disse kommer i forlengelsen av det generelle fredsarbeidet som den norske stat drev.

Fra den kalde krigen vet vi om en håndfull eksempler på konkret norsk fredsdiplomati. Hans Engen arbeidet som presseattaché i Norges FN-delegasjon og var utenriksminister Halvard Langes fortrolige. Han ble i 1950 kontaktet av en russer

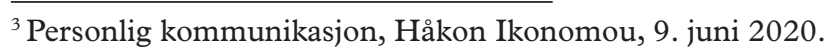


som arbeidet i FN-sekretariatet, Vasilij Kassaniev, som spurte om han kunne være mellommann mellom Sovjetunionen og USA. Engen etablerte en kanal til USAs utenriksminister Dean Acheson. Intet kom ut av formidlingen, men en kanal var blitt etablert (Alund, 2014, s. 34-35) og ble senere holdt ved like (Skogrand, 1995, s. 61-67, 248-251). Som FN-ambassadør sørget Engen for at Norge spilte en sentral rolle i arbeidet med å dempe Suez-krisen ved å opprette og videreføre United Nations Emergency Force (UNEF I) (Alund, 2014, s. 55). Senere var han, på initiativ fra den amerikanske utenriksministeren John Foster Dulles, mellommann mellom USA og enkelte arabiske stater i forbindelse med Libanon-krisen i 1958 og, på initiativ fra FNs generalsekretær Dag Hammarskjöld og som hans personlige representant, mellom Thailand og Kambodsja i 1960 (Alund, 2014, s. 86, 91). Både Lundestad (1999), Lange, Pharo og Østerud (2009, s. 19) og Alund (2014, s. 120) fremhever Engens meglerarbeid som en forløper for norsk megling - og også hvordan denne meglingen skjedde i forlengelsen av amerikansk politikk. Engens og UDs engasjement støtter vår hypotese nummer én, men merk at dette dreier seg om statlig virksomhet som ikke ble offentliggjort. Samfunnet er overhodet ikke involvert. Merk også at embetsverket i UD ikke engang ble informert om virksomheten, som dermed heller ikke på noen måte kunne integreres i norsk diplomati og utenrikspolitikk generelt.

Alle disse poengene kan også gjøres om Langes egen virksomhet som fredsdiplomat. Lange nøt stor tillit blant Norges vestlige allierte og ble brukt som hemmelig mekler mellom Island og Storbritannia i fiskerispørsmål i 1960 (Neumann \& Leira, 2005, s. 284). Under Vietnamkrigen, i årene 1967-1969, drev UD en bakkanal mellom Nord-Vietnam og USA i det som gjennom Pentagon-papirene er blitt kjent som Ohio-kanalen (etter bakkanalens amerikanske kodenavn) (Tamnes, 1997, s. 355356; Herring, 1983). Kanalen, som det hadde kostet adskillig å få etablert, gikk fra Nord-Vietnams ambassadør Loan i Beijing via Norges ambassadør Ålgard i Beijing og Norges utenriksminister Lyng til USAs ambassadør Tibbetts i Oslo. I 1971 ble UD kontaktet av Thailands utenriksminister Thanat Khoman, som ønsket å normalisere Thailands forhold til Kina og trengte en tilrettelegger (facilitator) (Utenriksdepartementet, 1971a). UD svarte positivt på henvendelsen, og den samme Ålgård formidlet kontakt (Utenriksdepartementet, 1971b). ${ }^{4}$ Dette styrker hypotese nummer én, men gitt at opptrinnet ennå venter på sin historiker, har vi for få holdepunkter for videre resonnementer.

Fra 1970-årene av og ut 1980-årene var Kirkens Nødhjelp (KN) aktiv i Etiopia/ Eritrea, og avla med jevne mellomrom rapport til den norske ambassaden i Nairobi om utviklingen. Fra 1985 av ble KNs mann, Jan A. Erichsen, sendemann mellom partene. UD kom derfra stadig sterkere inn som tilrettelegger. Christine SmithSimonsen (2014) har studert forløpet, og hun har konkludert med at formidlingen av kontakt via en norsk ikke-statlig organisasjon ( $\mathrm{KN}$ ), bruken av diplomater som

\footnotetext{
${ }^{4}$ Takk til Sven Lundbo, som gjorde oppmerksom på dette.
} 
opererte i samarbeid med KN, koordineringen internt i UD og, vil vi legge til, det faktum at det sett fra Addis Abeba dreiet seg om en intern konflikt, og ikke, som tidligere forløpere for Norges freds- og forsoningsdiplomati, om kontakt mellom to andre stater, gjør denne casen til en direkte forløper for integreringen og institusjonaliseringen av norsk freds- og forsoningsdiplomati. Nettopp disse likhetene, som strekker seg helt til personaloverlapp mellom diplomater som var aktive i Etiopia/ Eritrea like før den kalde krigens slutt og siden i fremforhandlingen av den såkalte Oslo-avtalen like etter, understreker imidlertid også at vi har å gjøre med en case som ikke forteller oss så mye om den perioden vi mangler kunnskap om, annet enn ved å forkorte den. Etiopia/Eritrea-casen er begynnelsen på integreringen og institusjonaliseringen av freds- og forsoningsdiplomatiet. Vi mangler dermed fortsatt kunnskap om de indirekte forløperne, og om de tre foreliggende hypotesene om dette diplomatiets suksess og relevans gjelder for disse indirekte forløperne. For å bøte på dette skal vi ta for oss en case som hittil bare har vært kjent fra én artikkel i Dagsavisen (tidligere Arbeiderbladet) 25. mars 2018 (Eide, 2018), og som ikke tidligere har vært studert, nemlig det såkalte Nobel-initiativet fra midten av 1960årene.

\section{Nobel-initiativet}

Det såkalte Nobel-initiativet sprang ut av en artikkel publisert i nettopp Arbeiderbladet 26. august 1966, og av påfølgende diskusjoner i en mindre gruppe om hvordan fred iVietnam kunne oppnås (Eide, 1966). Artikkelen var ført i pennen av Kjell Eide, en radiotekniker i forsvaret, og gir et godt innblikk i det ideologiske og analytiske grunnlaget for initiativet. 4. april 1968 markerte slutten på initiativet, da nøkkelfiguren Martin Luther King jr. ble myrdet. Mellom disse to datoene ble Nobel-initiativet drevet frem av en liten gruppe, hovedsakelig og opprinnelig bestående av nordmenn, og det ble omfavnet av den norske stat. Artikkelforfatteren, Kjell Eide, utfordret og godt hjulpet av avisens redaktør, Reidar Hirsti, samlet det som skulle utgjøre kjernen i gruppen. Det dreiet seg om fredsaktivist og leder i arkitektforeningen John Engh, rektor Otto Bastiansen fra Universitetet i Oslo og leder for Det teologiske fakultet Johan B. Hygen. Leder i Nobelkomiteen og tidligere finansminister i Gerhardsens samlingsregjering for Venstre, Gunnar Jahn, sluttet seg også til initiativet umiddelbart etter at han fratrådte i Nobelkomiteen ved utgangen av 1966 (Eide, 2018; Jahn, 1967b, s. 3290-3293; Langhelle, u.å.). Også den svenske sosialdemokraten Gunnar Myrdal var tidvis involvert i gruppens arbeid (Jahn, 1967b, s. 3290-3293; Wood, 1967a; Noel-Baker \& Pire, 1967a).

Prosessen fra idé til regjeringsbehandling er verdt å merke seg. I dette tilfellet blir en kronikk skrevet av en radiotekniker plukket opp av redaksjonen i arbeiderpressen, som så kobler inn deler av landets intellektuelle elite. Sistnevnte dels har og dels knytter de nødvendige internasjonale forbindelser, før initiativet til slutt plukkes opp av staten og blir gjenstand for regjeringsbehandling og etter hvert statlig 
politikk. Dette gir et godt bilde av en tidlig forløper til det samarbeidet mellom sivilsamfunn og stat som senere skulle prege norsk freds- og forsoningsdiplomati.

Initiativets utspring i Arbeiderbladet og kretsen rundt Reidar Hirsti gir et naturlig tyngdepunkt på norsk venstreside, hvor blant andre Kjell Eide, Otto Bastiansen og John Engh inngår. De var alle aktive i kampanjen mot atomvåpen og senere engasjert i striden om norsk basepolitikk, begge tett knyttet til norsk arbeiderbevegelse (Bjørklund, 1976; Njølstad, 2015). John Engh, Otto Bastiansen og Johan B. Hygen var for eksempel stiftende medlemmer av atommotstandsbevegelsen "De 13» (Lindstøl, 1978). At også LO bevilget penger til initiativet, styrker koblingen til arbeiderbevegelsen betraktelig. Som vi skal se, spilte også borgerlige politiske krefter en viktig rolle. Johan Hygen hørte hjemme her, og uten Gunnar Jahn og utenriksminister John Lyng (Høyre) er det vanskelig å se for seg at initiativet ville ha kommet så langt som det gjorde. Kjernegruppen $\mathrm{i}$ initiativet hadde også et sterkt religiøst preg. Johan B. Hygen var prest og religionsfilosof, Duncan Wood representerte kvekerne, Martin Luther King var pastor og borgerrettsforkjemper, og Dominique Pire var munk. Phillip og Francis Noel-Baker var kvekere og medlemmer av det britiske arbeiderpartiet (Encyclopædia Britannica, 2019).

I kronikken i Arbeiderbladet fra 1966 tegner ikke Eide opp noen spesifikk fremgangsmåte for hvordan fredsforhandlinger kan fremprovoseres, eller hvem som konkret skal stå for provokasjonen. I intervjuer en av oss gjorde med ham før hans død, fremgikk det at kronikken ikke var ment å være starten på et initiativ, men at redaktør Hirsti hadde utfordret ham til å sette handling bak ord og hadde satt ham i forbindelse med John Engh, Otto Bastiansen og Johan B. Hygen. Engh og Eide formulerte deretter et brev til Nobelkomiteen datert 27.09.1966, som legger frem den planen som kom til å bli styrende for initiativets arbeid - etablering av en nøytral delegasjon bestående av minst tre internasjonalt kjente og frittstående personer som skal gjennomføre en delegasjonsreise til henholdsvis Hanoi og Washington D.C. for å få klarhet i partenes faktiske forhandlingsposisjoner. Brevet spesifiserer riktignok ikke at delegasjonsdeltakerne måtte være nobelprisvinnere, men foreslår at Nobelkomiteen er rett institusjon til å oppnevne og utsende en slik delegasjon.

Nobelkomiteen ved Gunnar Jahn svarte i brev av 21.10.1966 at komiteen «ikke finner å kunne gi et positivt svar på anmodningen", da dette falt utenfor komiteens mandat, men at det likevel kunne vurderes dersom «komitéen var overbevist om det hensiktsmessige i det initiativ som blir foreslått i deres brev og at det var sannsynlig at det ville føre til positive resultater [...] dette [er] for tiden ikke tilfellet». Kun to måneder senere slutter Gunnar Jahn seg til initiativet etter sin avgang som leder i Nobelkomiteen, og 6. januar 1967 går det ut brev til samtlige nobelprisvinnere. Det synes derfor å være tilfellet at Gunnar Jahn har styrt gruppen over på en fremgangsmåte basert på en delegasjon av nobelprisvinnere, et format som var godt kjent for ham gjennom hans relasjon til Linus Pauling og sistnevntes mange fredsappeller, men særlig initiativet ovenfor Ho Chi Minh og Lyndon B. Johnson. Den 6. januar 1967 går det så ut brev til samtlige levende prisvinnere med forespørsel om støtte 
(Bastiansen et al., 1967). Røde Kors og FN-organisasjonene sender svar hvor de takker for brevet, men informerer om at de av naturlige årsaker ikke har mulighet til å delta. Samtlige individuelle prismottakere og kvekerorganisasjonen Friends World Committee for Consultation uttrykte sin fulle støtte til initiativet, med unntak av diplomaten Ralph Bunche, som da jobbet som fredsmekler for FN, og Canadas statsminister Lester B. Pearson.

Brevet fremlegger en plan for og anmodning om å støtte opp om å mobilisere en delegasjon bestående av fredsprisvinnere til å berede grunnen for forhandlinger mellom USA og Nord-Vietnam ved å etablere en bakkanal, basert på en tanke om at fredsprisvinnerne både kunne handle med den nødvendige legitimitet og mobilisere en internasjonal opinion, og at man gjennom en gruppe med prisvinnere ville kunne frembringe troverdig informasjon om de faktiske forhold og partenes forhandlingsposisjoner. Slik ville man også legge press på partene for å få finne en vei til fred. I samtiden fremsto forhandlingsgrunnlaget uklart, da begge parter i konflikten hevdet seg villige til å forhandle, men at motparten gjorde det umulig.

Imidlertid var det kun tre av de individuelle prisvinnerne som hadde mulighet og ønske om aktivt å engasjere seg i initiativet - Martin Luther King jr., Dominique Pire og Phillip Noel-Baker. I tillegg kom Duncan Wood, som representerte kvekerne. I februar 1967 er det så Gunnar Jahns tur til å sende brev til Nobelkomiteen. I brevet, datert 08.02.1967, anmodes komiteen om å slutte opp om initiativet. Den nye lederen i Nobelkomiteen svarer i et udatert brev ved å vise til «det prinsipielle standpunkt som ble utformet i brev av 21. oktober 1966 til Kjell Eide og John Engh» (Jahn \& Eide, 1967). Svaret skaper tydeligvis noe furore og provoserer frem klagebrev fra både Noel-Baker og Georges Pire (Noel-Baker \& Pire, 1967a; Langhelle, 1967).

Med unntak av King deltok samtlige involverte på et møte 9.-10. mars $1967 \mathrm{i}$ Oslo, som markerer formaliseringen av initiativet (Noel-Baker \& Pire, 1967b; Eide, 2018). Det sendes ut nok et brev til fredsprisvinnerne hvor det informeres om at initiativet formelt er opprettet, og om at administrasjonen av initiativet legges til Oslo. Dette til tross for at det av Gunnar Jahns dagbok fremkommer at Pire forsøkte å få administrasjonen av initiativet flyttet til Belgia. Brevet er undertegnet Dominique Pire og Phillip Noel-Baker. Det blir planlagt delegasjoner til Hanoi og Washington for å få klarhet i de respektive landenes forhandlingsposisjoner. Det skal også ha blitt undersøkt hvorvidt partene var villige til å ta imot en slik delegasjon, noe alle fire krigførende parter, Nord-Vietnam, Sør-Vietnam, USA og Nasjonal Frigjøringsfront (NLF), samtykket i (Eide, 2018). Ifølge Gunnar Jahn (1967b, s. 3297-3298) skulle henvendelsen om et konkret delegasjonsbesøk til USA rettes via den norske ambassaden i Washington D.C., mens henvendelsen til Sør-Vietnam skulle rettes via deres ambassader i London og Brussel. Det er uvisst om dette ble gjennomført.

Det blir deretter søkt økonomisk støtte fra UD og LO. Til tross for Gunnar Jahns bekymring om at «Nobelkomitéens innstilling til saken, som var meget kjølig, vil etter all sannsynlighet være en hindring for at den norske regjering tør komme med forslag om å bekoste reisen", bevilger UD 150000 kroner i støtte til prosjektet 
for året 1967, sum tilsvarende ca. 1,5 millioner i dagens kroneverdi (Jahn, 1967b, s. 3302-3304). ${ }^{5}$ Gunnar Jahn er i dagboken spesifikk på at beløpet er ment å dekke initiativets utgifter i 1967. LO bevilget også 15000 kroner (Jahn, 1967b, s. 33023304). Beslutningen om å gi støtte til initiativet ble gjort på regjeringskonferanse den 05.09.1967 på bakgrunn av r-notat fremsatt av utenriksministeren (Utenriksdepartementet, 1967). At saken ble behandlet på dette nivået, tyder på at saken ble opplevd å være så politisk sensitiv at det var naturlig å forankre saken i regjeringen. Det fremgår at støtten ble gitt spesifikt for å dekke reise til Moskva, Washington D.C. og Saigon. Behandlingen viser imidlertid også at det ikke bare er et statsorgan, men en koordinert stat som knytter an til dette samfunnsinitiativet. Merk imidlertid at bevilgningen blir ført under «tilfeldige utgifter». Det er altså ikke åpenhet om saken, verken nedover i departementrekkene eller utenfor statsapparatet.

John Lyng var godt kjent med den amerikanske interessen for informasjon vedrørende den nordvietnamesiske forhandlingsposisjonen gjennom Ohio-kanalen, som begynte sin aktivitet bare et par måneder før regjeringen vedtok støtte til Nobel-initiativet (Herring, 1983; National Archives, 1969/2011). Ohio-kanalen gikk via den norske sendemannen i Beijing, Ole Ålgard. Det virker rimelig å anta at Lyng så på et slikt initiativ som en opportun og naturlig forlengelse av arbeidet med Ohiokanalen. Norge var dog langt fra alene i å se verdien med å tilrettelegge for slik dialog. I løpet av Vietnamkrigen eksisterte en myriade av ulike kanaler og meklingsforsøk som til sammen involverte flere titalls aktører og stater. Det er også rimelig å anta at Lyng, i likhet med både Eide (1966) og Jahn (1967b), så en mulighet i slik aktivitet til å tjene både transatlantiske interesser samt å få slutt på krigen.

Besøket til Hanoi var først ut, men ble etter hvert avvist med henvisning til sikkerhetssituasjonen. I stedet ble det besluttet å møtes i Moskva, de både nasjonal frigjøringsfront og nordvietnamesiske myndigheter var representert. Det oppsto imidlertid komplikasjoner da det viste seg at Phillip Noel-Baker var for syk til å reise, og at Georges Pire ikke ønsket å reise alene (Jahn, 1967b, s. 3302-3304). Kjernegruppen tok da kontakt med Martin Luther King, som stilte seg positiv til å gjennomføre reisen, men som trakk seg i siste liten. Kjernegruppen besluttet derfor å sende Eide, Hygen og Wood som en slags fortropp for å berede grunnen for en fremtidig delegasjonsreise. Reisen til Moskva ble gjennomført 7.-12. oktober 1967, og det eksisterer nitide notater fra flere lange dager med møter som ble avholdt med både nordvietnamesiske myndigheter og Nasjonal frigjøringsfront (NLF) (Wood, 1967a). Besøket må sies å ha vært i hvert fall delvis vellykket, i den forstand at referatene inneholder utførlige beskrivelser av både nordvietnamesiske og NLFs forhandlingsposisjoner.

Etter Moskva-reisen møttes gruppen på William Penn House i London den 14. november 1967 (Wood, 1967b). Til stede var King, Eide, Hygen og Wood så vel som Francis Noel-Baker, Bill Rutherford og Andrew Young. Francis var sønn av Phillip Noel-Baker og sannsynligvis hans stedfortredende grunnet sin fars sviktende

\footnotetext{
${ }^{5}$ Omregnet fra 1967-kroner med Norges Banks inflasjonskalkulator.
} 
helse, mens Bill Rutherford og Andrew Young var del av følget til King. Formålet med møtet synes å ha vært å velge en leder for gruppen samt å planlegge veien videre. At ingen av de individuelle fredsprisvinnerne hadde deltatt på møtene i Moskva, ga nok et behov for å formalisere rollefordelingen i gruppen. Det ble besluttet at man skulle sende en tilsvarende delegasjon til Washington D.C. på omkring samme nivå bestående av sponsorgruppe (Eide, Hygen, Wood) samt representanter for NoelBaker og King - og at disse møtene skulle legge grunnlaget for en formell delegasjon bestående av fredsprisvinnere.

Ifølge Kjell Eide ble det også undertegnet en avtale mellom sponsorgruppen og King, hvor King eksplisitt utpekes som leder av initiativet og forplikter seg til å lede offisielle delegasjoner til Hanoi og Moskva våren eller sommeren 1968 (Eide, 2015). Valget av King var naturlig, gitt Philip Noel-Bakers sviktende helse og Dominique Pires skepsis til å representere initiativet alene, samt at Duncan Wood representerte en institusjonell heller enn en personlig prisvinner.

Den 22. november 1967 møter Eide og Hygen utenriksminister John Lyng på Victoria Terrasse (Colding, 1967a). I møtet ble besøket til Moskva og veien videre diskutert. Lyng hadde på forhånd mottatt og lest møtereferatene ført i pennen av Duncan Wood. Lyng legger i dette møtet press på Eide og Hygen for å få på plass et besøk til Hanoi, og for at fremtidige reiser må inkludere fredsprisvinnere. Den norske stats utenriksminister gir altså ikke bare støtte til samfunnsfremstøtet, men går også aktivt inn i arbeidet. Lyng uttrykker for øvrig også betenkeligheter rundt Kings dobbeltrolle ved en delegasjonsreise til USA. Lyng sikter etter all sannsynlighet til Kings borgerrettskamp og hans offentlige kritikk mot krigføringen i Vietnam, og til at dette ville kunne påvirke hvordan initiativet ville bli oppfattet på hjemmebane. Eide og Hygen vektlegger på sin side at et besøk til Washington D.C. vil styrke mulighetene for å få på plass et slikt besøk til Hanoi, men unnlater å si det som virker åpenbart i ettertid - man hadde ikke noe alternativ til en delegasjon ledet av King. Lyng presser videre på for at kjernegruppen sonderer med den amerikanske ambassaden i Oslo hvordan et slikt besøk ville bli mottatt (Jahn, 1967b, s. 3297-3298; Colding, 1967a). Det er ikke kjent om dette faktisk ble gjort. Av Gunnar Jahns dagbok (1967b) fremgår det også at Jahn og Lyng hadde forbindelse per telefon utenom de formelle møtene med kjernegruppen.

Et telegram fra King som henviser til utfordringer på hjemmebane i januar 1968, fører imidlertid til at delegasjonsreisen til Washington D.C., og dermed også den tiltenkt påfølgende delegasjonsreisen til Hanoi, utsettes i påvente av avklaring fra King (King, 1967; Jahn, 1967b, s. 3302-3304). 4. april 1968 blir King myrdet. Det markerer slutten på initiativet. Noel-Bakers helse tillot ikke reise, og Pire ønsket ikke å reise som eneste personlige prismottaker. Initiativet sto dermed uten frontfigur og manglet fredsprisvinnere med engasjement og ikke minst med helsen $\mathrm{i}$ behold. Det ble dødsstøtet for Nobel-initiativet. Den norske statlige rollen i initiativet synes ikke å ha vært offentlig kjent i samtiden, selv om initiativet regelmessig ble omtalt i pressen. 


\section{Nobel-initiativets betydning som forelegg for norsk freds- og forsoningsdiplomati}

Det ble aldri noe av en norsk tilretteleggende tredjemannsrolle mellom USA og Nord-Vietnam. Det som interesserer oss her, er imidlertid ikke fredsdiplomatiets effekt som sådan, men derimot hvordan forholdet mellom samfunn og stat har utviklet seg i norsk freds- og forsoningsdiplomati. I dette henseendet er Nobel-initiativet, så vidt vites, det første historiske eksemplet på at staten omfavner et samfunnsinitiativ til fredsdiplomati, og et forelegg for norsk freds- og forsoningsdiplomati slik det skulle komme til å bli institusjonalisert et kvart århundre senere. At dette samfunnsinitiativet først retter seg mot et resultat av Nobelinstituttets virksomhet (fredsprisvinnere), er i de beste historiske tradisjoner, for det var historisk sett her ekspertisen på internasjonal politikk og norsk utenrikspolitikk befant seg (Knutsen, Leira \& Neumann, 2016). Det samme kan sies om det faktum at Nobelinstituttets virksomhet dermed også blir bindeledd mellom samfunnsinitiativet og den norske stat, for historisk sett har det vært staten som har utpekt dem som så har utpekt nobelprisvinnerne. Johnsen (2015) argumenterer endog overbevisende for at Nobelinstituttets organisering og virksomhet gjør det til et såkalt ideologisk statsapparat.

At staten støttet initiativet, er det ingen tvil om. Regjeringen nedfelte bevilgningen $i$ et såkalt $r$-notat, og beslutningen ble tatt i regjering - det vil si av regjeringen samlet. Stort mer formelt blir det ikke i norsk statsforvaltning. Utenriksminister John Lyng møtte selv initiativtagerne og deltok i utformingen av deres arbeid. Utenriksdepartementet delte også redigerte rapporter fra Moskva med den amerikanske ambassaden i Oslo. Av UDs arkiv fremgår det at det var hektisk og betydelig aktivitet knyttet til initiativet innen UD, selv om man understreket at det var et initiativ $i$ «privat regi». Det fremgår også at kontakten mellom kjernegruppen og UD var betydelig mer utstrakt enn det som fremgår av annet arkivmateriale. Det er ikke utelukket at en viss institusjonell læring fant sted i Lyngs departement, for i saksdokumentene går det frem at blant diplomatene som var tettest på saken, ble to av dem senere utenriksråd - nemlig ekspedisjonssjef Sverre Gjellum (1972-1977) og Kjell Colding (1992-1996). ${ }^{6}$ Saken ble også fulgt opp av statssekretær Jacobsen, ekspedisjonssjef Ansteensen, byråsjef Christiansen og konsulentene Vraalsen og Sandegren. Vraalsen ble senere bistandsminister i Jan P. Syses regjering (1989-1990), ambassadør i Washington D.C. (1996-2001) og FNs spesialutsending for Sudan (1998-2004). Ansteensen og Vraalsen var sentrale spillere også i arbeidet med Ohio-kanalen, og Vraalsen besøkte Hanoi sammen med Ålgård i 1968.

Antallet personer som hadde kjennskap til saken i UD, synes å ha vært begrenset. Imidlertid foreligger det dokumentasjon på at informasjon om initiativet ble distribuert til flere utenriksstasjoner, og at saken fikk tett oppfølgning i politisk avdeling og fra statssekretærene her hjemme. Pressedekningen av initiativet, både i Norge og

${ }^{6}$ Den tredje var Sven Knudsen. 
ute, er behørig dokumentert i UDs arkivmaterialer (Utenriksdepartementet 19671969).

For å fastslå i hvilken grad den nye kunnskapen om Nobel-initiativet forandrer vårt syn på norsk freds- og forsoningsdiplomatis fremvekst i stort, kan vi nå vende tilbake til de tre hypotesene vi fremsatte innledningsvis, under navnene fredstanken, fravær av politisk realismetradisjon og raison de système.

Vår hypotese nummer én, om hvorfor Norge er engasjert i freds- og forsoningsdiplomati i adskillig høyere grad enn andre stater, pekte på en kristen, protestantisk arv som ble videreført av norsk og skandinavisk arbeiderbevegelse. Vår case, Nobel-initiativet fra 1966, støtter denne hypotesen, for den dreier seg om et fredsinitiativ som ble fremført av kretsen omkring Reidar Hirsti. Han var landsmøtevalgt redaktør av Arbeiderpartiets sentrale partiorgan, Arbeiderbladet (1963-1974). En av de fire i den norske initiativgruppen var professor i teologi, og samtlige utenlandske involverte var sterkt religiøst aktive. Tyngdepunktet $\mathrm{i}$ den norske initiativgruppen synes imidlertid å være kampen mot atomvåpen og kanskje mer spesifikt organisasjonen «De 13» (De 13, 1960). Tanken om å bruke fredsprisvinnere til å bygge folkeopinion er i seg selv interessant og høyst sannsynlig inspirert av nettopp kampen mot atomvåpen. Fremgangsmåten bærer sterke likhetstrekk til Albert Schweitzers kampanje mot atomprøvesprengningene og Linus Paulings appell for fred i Vietnam samt et utall fredsmøter fra begynnelsen av sekstitallet med fredsprisvinnere som sponsorer som for eksempel Verdens fredsråds fredsmøte i Moskva i 1962. Den nære kontakten mellom deler av kjernegruppen og henholdsvis Schweitzer og Pauling samt planen om å bruke fredsprisvinnere som frontfigurer gir god grunn til å anta at initiativets fremgangsmåte var sterkt inspirert av Schweitzers og Paulings tidligere appeller og initiativer. ${ }^{7}$

Vår hypotese nummer to, som kompletterte den første, var at den suverene norske staten som kom til i 1905, steg frem i et diskursivt miljø der politisk realistisk tenkning om utenrikspolitikk sto svært mye svakere enn i noen annen suveren, europeisk samtidig stat, først og fremst på grunn av Norges svake aristokratiske tradisjon. Vår fremlegging av Nobel-initiativet fører - i tråd med påstanden om at realismen styrkes innen UD, spesielt i tiden etter andre verdenskrig - til at denne hypotesen må spesifiseres. Et sentralt tema i litteraturen om arbeiderpartistatens utenrikspolitikk har vært dragkampen mellom partiets høyre- og venstreside om alliansepolitikken, som blant annet førte til venstresideavskallinger i 1949 (protester mot NATOmedlemskapet), 1958 (påskeopprøret, eksklusjon av Sosialistisk Studentlag), 1961 (dannelsen av Sosialistisk Folkeparti) og 1973 (Arbeiderbevegelsens informasjonskomité mot norsk medlemskap i EF [AIK]). Det miljøet som målbar Nobel-initiativet, var hjemmehørende på partiets venstreside, men fikk like fullt Arbeiderpartiets

\footnotetext{
${ }^{7}$ Imidlertid har det ikke lykkes forfatterne å finne noen direkte kobling eller korrespondanse som kobler de to initiativene sammen. Se for øvrig sammenfatning av korrespondanse med Pauling i Schou (1966) og Hygen (1961), samt Schweitzer i Jahn (1967b) og Angell et al. (1961).
} 
imprimatur. Høyresiden i partiet, der blant annet tidligere utenriksminister og realist Halvard Lange hørte hjemme, fulgte altså i dette tilfellet venstresiden. John Lyng, som var Høyres utenriksminister i en borgerlig koalisjonsregjering, var også realist. Gitt at både Lange og Lyng også var atlantister og dermed neppe ville ha gjort stort uten å rådføre seg med representanter for USA, kan vi imidlertid ikke entydig hevde at tesen om at den politiske realismen sto svakt i Norge, og om at dette skapte bedre kår for fredsdiplomati enn hva som fantes i land med sterkere politisk realistiske tradisjoner, styrkes. En vel så rimelig tolkning er at politisk realistiske hensyn, først og fremst pleiingen av forholdet til USA, i dette tilfellet falt sammen med en interesse for å drive fredsdiplomati. Dette ville i så fall være en interessant 180-gradersvri på vår hypotese nummer to, at fredsarbeid står sterkere i Norge enn i Sverige og Danmark på grunn av manglende norsk realismetenkning, for det ville bety at det var nettopp UDs økende realisme og oppgradering av alliansetilknytning som førte til vendingen mot fredsdiplomati, på vegne av landets sterkeste allierte som Norge så gjerne ville være en nyttig klient for.

Vår tredje hypotese, om hvordan fred og forsoning kom til å stå så sentralt i norsk utenrikspolitikk, dreiet seg om såkalt raison de système, altså en grunn til at en gitt stat vil ha interesse av å opprettholde og styrke det statssystemet den er en del av, i den form det eksisterer. Det vi frem til nå har visst om overtagelse av fredsdiplomati, har indikert at dette ikke skjer historisk før mot slutten av den kalde krigen, altså når omkostningene ved å bygge ut diplomatisk aktivitet som ikke er direkte nødvendig i et politisk realistisk perspektiv, blir mindre. Vår case utfordrer ikke dette direkte, for det dreier seg ikke om freds- og forsoningsdiplomati i betydningen tilrettelegging av fredsdialog mellom et regime og en intern opposisjon, slik tilfellet var i Etiopia/Eritrea i 1980-årene og i påfølgende sekvenser. Vi har påvist at staten støtter et privat fredsinitiativ, men dette fredsinitiativet siktet mot tilrettelegging av dialog mellom to stater, til forskjell fra mellom et regime og en intern opposisjon. Vår case er altså en forløper for dagens fred- og forsoningsdiplomati, i den forstand at den foregriper samspillet mellom det norske samfunn og den norske stat, men den er bare en indirekte forløper, for det diplomatiske arbeidet som staten tar sikte på å utføre, er en tradisjonell diplomatisk tredjemannsrolle - tilrettelegging mellom stater - snarere enn en ny diplomatisk funksjon - mediering internt i en stat.

Den akademiske diskusjonen om norsk fredsdiplomati har så langt konsentrert seg om tiårene før og etter at Norge ble en suveren stat i 1905 på den ene siden og de tre siste årene med den økende institusjonaliseringen av freds- og forsoningsarbeid i UD på den andre. Mellom slutten av 1920-årene og midten av 1980-årene har det med få unntak vært en uutforsket periode på seks tiår. Ved å trekke Nobel-initiativet fra midten av 1960-årene inn har vi redusert denne perioden med en tredjedel, til omkring fire tiår.

Nobel-initiativet gjør det også mulig å postulere en linje i norsk freds- og forsoningsdiplomati. Den går fra løse folkeforbundrelaterte forelegg i margen av norsk UD i 1920-årene (det multilaterale diplomatiet utøvet av Erik Colban og 
Fridtjof Nansen på oppdrag fra Folkeforbundet), der tilretteleggingen skjer mellom regimer og opposisjonsgrupper via UDs tilrettelegging for bakkanaler mellom stater i 1950- og 1960-årene (det bilaterale diplomatiet utøvet av Hans Engen og Halvard Lange på oppdrag fra Den norske stat) og det borgerinitierte Nobel-initiativet om tilrettelegging mellom stater som foregikk med UDs støtte, til Kirkens Nødhjelps og UDs tilrettelegging mellom det etiopiske regimet og den eritreiske opposisjonen i 1980-årene og norsk freds- og forsoningsdiplomati i 1980-årene. Om vi ser denne linjen i lys av vår hypotese nummer tre, at Norge driver freds- og forsoningsarbeid for å forebygge at konflikter brer seg, og med dette å styrke den bestående verdensordenen, kan vi fremsette følgende påstand: Norsk UD og dermed den norske stat har vært involvert i freds- og forsoningsarbeid i den grad og i den form de internasjonale konjunkturene har tillatt det. I 1920-årene var det spillerom for tilrettelegging mellom regimer og opposisjon. Norge gikk inn i arbeidet. I 1930-årene og 1940årene var det intet spillerom. I 1950- og 1960-årene var det spillerom for å bruke klientrollen overfor USA til å tilrettelegge for bakkanaler. Norge gikk inn i arbeidet. I 1970-årene forsvant spillerommet igjen, men da det kom tilbake etter den såkalte andre kalde krigen i første halvdel av 1980-årene, grep Norge igjen muligheten til å drive freds- og forsoningsdiplomati og har gjort det siden. For en liten stat med en åpen økonomi er det et godt strategisk grep å arbeide for å dempe og helst fjerne konflikter og utfordringer som utfordrer en verdensorden som passer en slik stat svært godt. Norsk freds- og forsoningsdiplomati har altså vært, og er fortsatt, en tjeneste som Norge yter verden, samtidig som den er i Norges egeninteresse.

\section{Om forfatterne}

Martin Eide er rådgiver i Utenriksdepartementet og sønnesønn av Eide som er omtalt i artikkelen.

Iver B. Neumann er direktør ved Fridtjof Nansens Institutt. Hans siste bok er Diplomatic tenses: Past, present, future (Manchester University Press, 2020). Han er årets vinner av Fridtjof Nansens belønning for fremragende forskning.

\section{Referanser}

\section{Primærkilder}

Angell, N. et al. (1961). Declaration of the Nobel Peace Prize winners [Avskrift]. Nobelkomiteen, møter 19661969. Den Norske Nobelkomites arkiver, Det Norske Nobelinstitutt, Oslo.

Ball, G. (1965, 21. april). Memorandum from the Under Secretary of State (Ball) to President Fohnson. Johnson Library (National Security File, Country File, Vietnam, Political Track Paper). Austin, TX: Johnson Library.

Bastiansen, O. et al. (1967). Proposal for an initiative for negotiations in the Vietnam conflict. 6. januar 1967. Hentet 25. november 2015 fra http://www.thekingcenter.org/archive/document/norwegian-peace-initiative

Bjørklund, T. (1976). Atomprotestkampanjen. Pax Leksikon. Oslo: Pax Forlag.

Colban, E. (1952) Femti år. Oslo: Aschehoug. 


\section{Nobel-initiativet fra 1966 og den lange linjen i norsk freds-og forsoningsdiplomati}

Colding, K. (1967a). Nobelpristagernes initiativ for fred i Vietnam. Utenriksdepartementet, 22. november 1967. (RA/PA-0672 John Lyng. Serie FK, eske 58, mappe 6). Riksarkivet, Oslo.

Colding, K. (1967b). Nobelpristagernes initiativ for fred i Vietnam. Utenriksdepartementet, 27. november 1967. (RA/PA-0672 John Lyng. Serie FK, eske 58, mappe 6). Riksarkivet, Oslo.

De 13. (1960). Protest mot atomvåpen [Flyveblad]. Gunnar Jahns Privatarkiv, Nasjonalbibliotekets arkiv (Ms4* 3088:C8). Nasjonalbiblioteket, Oslo.

Eide, K. (1966, 26. august). Fred i Vietnam. Arbeiderbladet, kronikk.

Eide, K. (2015). Lydopptak av intervjuer. Heggedal, september og desember 2015. I familien Eides eie.

Eide, K. (2018, 25. april). Fredsinitiativet mot Vietnam. Dagsavisen, kronikk.

Eide, K. \& Engh, J. (1966). [Brev vedr. initiativ for fred i Vietnam, datert 27. september]. Nobelkomiteen, korrespondanse 1965-1974. Den Norske Nobelkomites arkiver, Det Norske Nobelinstitutt, Oslo.

Encyclopædia Britannica. (2019). Phillip fohn Noel-Baker. Hentet 26. mars 2020 fra https://www.britannica. com/biography/Philip-John-Noel-Baker-Baron-Noel-Baker

Finansdepartementet. (2019). Statsbudsjettet (Prop. 1 S (2019-2020)). Hentet 3. mars 2020 fra https://www. regjeringen.no/no/dokumenter/prop.-1-s-gul-bok-20192020/id2671985/?ch=1

Goldberg, A. (1967). Tale på Howard universitet 19. februar 1967 som trykket iVI bd. s. 36-44, National Archives (2011). Report of the Office of the Secretary of Defense Vietnam Task Force [The Pentagon Papers, 1969].

Herring, G. C. (Red.) (1983). The secret diplomacy of the Vietnam War: The negotiating volumes of the Pentagon Papers. Austin, TX: University of Texas Press.

Hygen, J. B. (1961). [Brev adressert til Gunnar Jahn]. Spesiell korrespondanse: Gunnar Jahn. Den Norske Nobelkomites arkiver, Det Norske Nobelinstitutt, Oslo.

Jahn, G. (1967a). [Takkebrev til utenriksminister John Lyng, datert 21. september 1967]. Upublisert. Kjell Eides privatarkiv.

Jahn, G. (1967b). Dagboken. 1964-1967. Nasjonalbiblioteket (Ms4^ 2579:24). Nasjonalbiblioteket, Oslo.

Jahn, G. \& Eide, K. (1967). [Brev til nobelkomiteen, datert 8. februar 1967]. Nobelkomiteen (korrespondanse 1965-1974). Den Norske Nobelkomites arkiver, Det Norske Nobelinstitutt, Oslo.

King, M. L. (1967). [Telegram til Kjell Eide av 10. oktober 1967; 29. januar 1968]. Hentet 25. november 2015 fra http://www.thekingcenter.org/archive/theme/1865

Langhelle, N. (u.å.). [Brev vedr. nobelinitiativet, ukjent adressat]. Nobelkomiteen (korrespondanse 19651974). Den Norske Nobelkomites arkiver, Det Norske Nobelinstitutt, Oslo.

Langhelle, N. (1967). [Likelydende brev til hhv. Georges Pire og Phillip Noel-Baker, svar på fg.klage, datert 17. mars 1967]. Nobelkomiteen (korrespondanse 1965-1974). Den Norske Nobelkomites arkiver, Det Norske Nobelinstitutt, Oslo.

Lindstøl, A. (1978). De 13. Protest mot atomvåpen - et utenomparlamentarisk initiativ under atomdebatten $i$ Norge våren 1961 (Hovedoppgave i historie). Universitet i Oslo, Oslo.

National Archives. (1969/2011). Report of the office of the Secretary of Defense Vietnam task force [The Pentagon Papers]. Hentet 27. mars 2020 fra https://www.archives.gov/research/pentagon-papers

Noel-Baker, P. \& Pire, G. D. (1967a). [Brev til Nobelkomiteens leder, datert 10.mars 1967]. Nobelkomiteen, korrespondanse 1965-1974. Den Norske Nobelkomites arkiver, Det Norske Nobelinstitutt, Oslo.

Noel-Baker, P. \& Pire. G. D. (1967). Initiative for peace in Vietnam. (Upublisert manuskript). Kjell Eides privatarkiv, i familiens eie.

Schou, A. (1966). [Brev til Langhelle m. vedlegg. Datert 5. oktober 1966]. Nobelkomiteen (korrespondanse 1965-1974). Den Norske Nobelkomites arkiver, Det Norske Nobelinstitutt, Oslo.

Utenriksdepartementet. (1967). Initiativ av nobelpristagere for fred i Vietnam. Henvendelse om finansiell støtte [R-notat av 28. august 1967]. (John Lyngs privatarkiv RA/PA-0672, Arkivverket. Fk, eske 58, mappe 6 Nobelpristagere for fred iVietnam). Riksarkivet, Oslo.

Utenriksdepartementet. (1967-1969). Sør-Vietnam: Nobelpristakeres fredsaksjoner (RA/S-6794). Utenriksdepartementet, hovedarkiv (serie Daa - Hovedklasse 1-25, eske L0969: Verdenspolitikk. Fremmede staters politikk. Generelt. 2 mapper. (1967-1969)). Riksarkivet, Oslo. Hentet 3. august 2020 fra https://media. digitalarkivet.no/db/contents/126907

Utenriksdepartementet. (1971a). Telegram fra Peking til UD. Datert 31. mars 1971. UD, ad-doss 25 4/33, II. Riksarkivet.

Utenriksdepartementet. (1971b). Brev. Datert 6. november 1971. UD, ad-doss 25 4/98. Riksarkivet.

Van Dong, P. (1965). Four points [tale]. Statsminister Pham Van Dong til Sør-Vietnams nasjonalforsamling. 8. april 1965.

White House Press Release. (1966). Fourteen points for peace in Southeast Asia, 7. januar 1966. 


\section{Martin Eide og Iver B. Neumann}

Wood, D. (1967a). Mission of Nobel Prize winners for a peaceful solution inVietnam. 14. november 1967 (Upublisert manuskript). Kjell Eides privatarkiv, i familiens eie.

Wood, D. (1967b). Reports on interviews in Moscow (Upublisert manuskript, 1.A. p. 5). Kjell Eides privatarkiv, i familiens eie.

\section{Sekundærkilder}

Agøy, N. I. (2000). Et floket partnerskap: fredsbevegelsen og arbeiderbevegelsen til 1940. Arbeiderhistorie, 14, 81-99.

Alund, A. (2014). Hans Engen: en utenrikspolitisk biografi. (Masteroppgave). Universitetet i Oslo, Oslo. Hentet fra http://urn.nb.no/URN:NBN:no-46789

Buzan, B. \& Wæver, O. (2003). Regions and powers. Cambridge, England: Cambridge University Press.

de Carvalho, B. \& Neumann, I. B. (Red.). (2015). Small state status seeking. Norway's quest for international standing. London, England: Routledge.

Der Derian, J. (1987). On diplomacy. Oxford, England: Blackwell.

Dumbrell, J. \& Ellis, S. (2003). British involvement in Vietnam peace initiatives, 1966-1967: Marigolds, sunflowers, and «Kosygin week». Diplomatic History, 27(1), 113-149.

Fixdal, M. C. (Red.). (2016). Fredsmegling i teori og praksis. Oslo: Cappelen Damm Akademisk.

Gettleman, M. E. (1995). Vietnam and America: A documented history. New York: Grove Press.

Gram-Skjoldager, K. \& Ikonomou, H. A. (2019). Making sense of the League of Nations Secretariat: Historiographical and conceptual reflections on early international public administration. European History Quarterly, 49(3), 420-444.

Gram-Skjoldager, K., Ikonomou, H. A. \& Kahlert, T. (2019). Scandinavians and the League of Nations Secretariat, 1919-1946. Scandinavian fournal of History, 44(4), 454-483.

Harpviken, K. B. \& Skjelsbæk, I. (2010). Tilslørt fredspolitikk. Nytt Norsk Tidsskrift, 27(4), 379-388.

Haug, K. E. (2012). Folkeforbundet og krigens bekjempelse: norsk utenrikspolitikk mellom realisme og idealisme (Doktoravhandling). Norges teknisk-naturvitenskapelige universitet.

Johnsen, I. (2015). Gifts favour the giver: Norway, status and the Nobel Peace Prize. I B. de Carvalho \& I. B. Neumanns (Red.), Small state status seeking: Norway's quest for international standing (s. 108-125). London, England: Routledge.

Knutsen, T., Leira, H. \& Neumann, I. B. (2016). Norsk utenrikspolitikks idéhistorie, 1890-1940. Oslo: Universitetsforlaget.

Kustermans, J. (2020). Peace: A Conceptual History. Under utarbeidelse.

Lange, E., Pharo, H. Ø. \& Østerud, Ø. (2009). Utenrikspolitikken etter den kalde krigen. I E. Lange, H. Ø. Pharo \& Ø. Østerud (Red.), Vendepunkter $i$ norsk utenrikspolitikk: Nye internasjonale vilkår etter den kalde krigen. Oslo: Unipub.

Leira, H. (2004). «Hele vort folk er naturlige og fødte Fredsvenner»: Norsk fredstenkning fram til 1906. Historisk tidsskrift, 83(2), 153-180.

Leira, H. (2005). Folket og freden: Utviklingstrekk i norsk fredsdiskurs 1890-2005. Internasjonal Politikk, 63(2-3), 135-160.

Liland, F. \& Kjerland, K. A. (2003). Norsk utviklingshjelps historie 3: 1989-2002: På bred front. Bergen: Fagbokforlaget.

Lode, K. (1997). The peace process in Mali: Oiling the works? Security Dialogue, 28(4), 409-424.

Lundestad, G. (1999). Lange linjer i norsk utenrikspolitikk. Internasjonal Politikk, 57(2), 271-293.

Neumann, I. B. (2015). Institutionalizing peace and reconciliation diplomacy: Third-party reconciliation as systems maintenance. I O. J. Sending, V. Pouliot \& I. B. Neumann (Red.), Diplomacy and the making of world politics (s. 140-167). Cambridge, England: Cambridge University Press.

Neumann, I. B. \& Leira, H. (2005). Aktiv og avventende. Utenrikstjenestens liv 1905-2005. Oslo: Pax Forlag.

Nissen, A. E. \& Waage, H. H. (2015). Weak third parties and ripening: Revisiting Norwegian interventions in Guatemala and the Israeli-Palestinian conflict. International Negotiation, 20(1-3), 389-413.

Njølstad, O. (2015). Atomfrykt. Norgeshistorie.no. Hentet 20. mars 2020 fra https://www.norgeshistorie.no/ velferdsstat-og-vestvending/1816-atomfrykt.html

Pharo, H. (2005). Den norske fredstradisjonen - et forskningsprosjekt. Historisk tidsskrift, 84(2), $239-255$.

Riste, O. (2003). Ideal og eigeninteresser: Utviklinga av den norske utanrikspolitiske tradisjonen. I S. G. Holtsmark, H. Ø. Pharo 6 R. Tamnes (Red.), Motstrøms. Olav Riste og norsk internasjonal historieskrivning (s. 53-88). Oslo: Cappelen Akademisk Forlag. 
Skogrand, K. (1994). Norge og Koreaspørsmålet 1945-1953. (Hovedoppgave i historie). Universitetet i Oslo, Oslo.

Skogrand, K. (1995). Vikarierende aktører og asymmetriske allianser: Norge og Koreakrigen 1950-1953. Internasjonal Politikk, (3), 285-306.

Skånland, Ø. H. (2010). «Norway Is a Peace Nation»: A discourse analytic reading of the Norwegian peace engagement. Cooperation and Conflict, 45(1), 34-54.

Smith-Simonsen, C. (2014). Eritrea-initiativene - En forløper for Den norske modellen innen fred og forsoning. Internasjonal Politikk, 72(2), 175-197.

Stachurska-Kounta, M. (2017). Norway and the League of Nations 1919-1939. A small state's quest for international peace (Doktoravhandling). Universitetet i Oslo, Oslo.

Tamnes, R. (1997). Norsk utenrikspolitisk historie: Bd. 6. Oljealder. Oslo: Universitetsforlaget.

Tvedt, T. (2003). Utviklingshjelp, utenrikspolitikk og makt. Den norske modellen. Oslo: Gyldendal Akademisk Forlag.

\section{Abstract in English \\ The Nobel Initiative from 1966 and the Long Lines in \\ Norwegian Peace and Reconciliation Diplomacy}

Norway was the first state to institutionalise peace and reconciliation work as part of its overall diplomacy. As it emerged from the mid-1980s onwards, peace and reconciliation diplomacy has had two characteristics: it has been carried out by state and society groups in tandem, and it has targeted reconciling a regime and an internal opposition to that regime. The bulk of the article presents a 1966 initiative by a group of concerned Norwegian citizens to launch a back channel for American and North Vietnamese peace talks by mobilising winners of the Nobel Peace Prize, and demonstrates that this initiative received political, administrative and economic help from the Norwegian state. This makes it a precursor of today's peace and reconciliation initiative. Given the fledgling examples of Norwegian peace and reconciliation work that we find in the margins of the League of Nations during the 1920s, knowledge about the Nobel Initiative of 1966 warrants the claim that, for the past hundred years, Norway has consistently attempted peace and reconciliation work to the extent and in the form allowed by international conditions.

Keywords: peace diplomacy $\cdot$ peace and reconciliation $\cdot$ Norwegian foreign policy 